\title{
ИНСЕКТИЦИДНЫЕ СВОЙСТВА Bacillus thuringiensis var. israelensis. СоОбщеНИе ІІ. СРАВНИТЕЛЬНЫЙ МОРФОЛОГИЧЕСКИЙ И МОЛЕКУЛЯРНО-ГЕНЕТИЧЕСКИЙ АНАЛИЗ КРИСТАЛЛОГЕННЫХ И АКРИСТАЛЛОГЕННЫХ ШТАММОВ*
}

\author{
В.П. ЕРМОЛОВА, С.Д. ГРИШЕЧКИНА, М.Е. БЕЛОУСОВА, К.С. АНТОНЕЦ, \\ А.А. НИЖНИКОВ
}

Бактерии Bacillus thuringiensis var. israelensis - основной агент биологической защиты от кровососущих двукрылых насекомых, многие из которых являются переносчиками трансмиссивных болезней сельскохозяйственных животных. Штаммы-продуценты для производства инсектицидных препаратов выделяют из природных объектов, получают посредством селекции ранее использованных изолятов, скрининга генетических коллекций и генной или геномной инженерии. При этом вопрос сохранности и контроля практически ценных свойств штаммов остается ключевым. Биопрепараты представляют существенный интерес в связи с их значительными преимуществами перед химическими пестицидами и рассматриваются в современных системах сельского хозяйства в качестве экологически и социально приоритетных альтернатив агрохимикатов. В представленной работе нами выполнен первый комплексный сравнительный анализ кристаллогенных и акристаллогенных вариантов Bacillus thuringiensis var. israelensis $\left(\mathrm{BtH}_{14}\right)$, выделенных после хранения штамма в разных режимах. У кристаллогенных вариантов методом полимеразной цепной реакции (ПЦР) впервые выявлены гены, кодирующие целевые инсектицидные токсины Cry4 и Cry11, и показано, что акристаллогенные формы этих генов лишены. Установлено, что у кристаллогенных вариантов культуральная жидкость приблизительно в 7000 раз активнее в отношении личинок Aedes aegypti чем у акристаллогнных. Целью настоящего исследования было сопоставление морфологических, биохимических, технологических, ларвицидных свойств кристаллогенных и акристаллогенных штаммов бактерии $\left(\mathrm{BtH}_{14}\right)$ и проверка наличия у них генов, кодирующих энтомоцидные токсины Сry, которые относятся к ключевым детерминантам вирулентности. Изучали штаммы 404, 87 (хранились 28 лет методом лиофилизации, затем 2 года в пробирках на скошенном рыбном агаре - РА с пересевом каждые 6 мес), штамм 7-1/23 (хранился 28 лет в кристаллах $\mathrm{NaCl}$, затем 2 года в культуральной жидкости - КЖ при температуре $\left.3{ }^{\circ} \mathrm{C}\right)$. Культуры рассевали методом истощающегося мазка на РА в чашках Петри. На 7-е сут роста при $30{ }^{\circ}$ С отбирали кристаллогенные $(404 / 14,87 / 21,7-1 / 23-4)$ и акристаллогенные (404/19, $87 / 33,7-1 / 23-8)$ варианты методом световой микроскопии, используя краситель черный анилиновый. У вариантов не выявили различий по морфологии колоний на РА в чашках Петри: колонии были плоские, матовые, серовато-белые, шероховатые, округлые, структура мелкозернистая, консистенция вязкая. Изучение морфологии вегетативной культуры, основных биохимических свойств (образование ацетилметилкарбинола, лецитиназы, использование углеводов, расщепление крахмала и др.) и оценка титра на дрожже-полисахаридной среде также не показали различий. Продуктивность вариантов 404/14, 87/21, 7-1/23-4 и 404/19, 87/33, 7-1/23-8 была в пределах соответственно $(3,36-4,02) \times 10^{9}$ и $(3,74-4,13) \times 10^{9}$ КОЕ/мл. Ларвицидная активность кристаллогенных вариантов, которая выражалась в ЛК дл $_{5}$ д $\mathrm{L}_{4}$ Aedes aegypti, составляла $(0,12-0,16) \times 10^{-3} \%$, акристаллогенные варианты были неактивными в пределах следующих общепринятых разведений $\left(\times 10^{-3} \%\right): 1,0 ; 0,5 ; 0,25 ; 0,125$ и 0,06. Их $1 \%$ суспензия (в 7000 раз большая концентрация) вызывали гибель 22-39\% личинок комаров через 24 ч, тогда как та же концентрация активных вариантов приводила к $100 \%$ гибели насекомых уже через 15 мин. Обнаружено, что КЖ акристаллогенных вариантов через 12 ч образовывала осадок и надосадочный слой, а кристаллогенных - оставалась в состоянии взвеси. Исследуемые варианты ВtН 14 были также впервые проанализированы на наличие генов, кодирующих инсектицидные токсины. Результаты амплификации с Bti-специфичными праймерами подтвердили принадлежность кристаллогенных и акристаллогенных вариантов к ВыН 14. Установлено, что варианты 404/14, 87/21, 7-1/23-4 несут гены, кодирующие инсектицидные токсины Cry4 и Cry11, в то время как акристаллогенные варианты 404/19, 87/33, 7-1/23-8 лишены этих генов, что согласуется с отсутствием у них активности в отношении комаров $A$. aegypti.

Ключевые слова: Bacillus thuringiensis, культуральная жидкость, ларвицидная активность, энтомоцидные токсины, Cry4, Cry11.

* Работа поддержана проектом прикладных научных исследований и экспериментальных разработок (ПНИЭР) по лоту шифр 2017-14-579-0030 по теме: «Создание микробиологических препаратов для расширения адаптационного потенциала сельскохозяйственных культур по питанию, устойчивости к стрессам и фитопатогенам» (шифр заявки 2017-14-579-0030-013), соглашение № 14.607.21.0178, уникальный идентификатор работ (проекта) RFMEFI60717X0178. 
Кровососущие комары и мошки из отряда Двукрылые (Diptera), которые являются переносчиками опасных инфекций человека и животных, наносят существенный урон животноводству. Bacillus thuringiensis subsp. israelensis $\left(\mathrm{BtH}_{14}\right)$ - эффективный бактериальный агент контроля численности личинок двукрылых, используемый по всему миру. Препараты на основе этой бактерии применяются в широком диапазоне мест обитания целевых насекомых, не вызывают у них резистентности и не оказывают негативного воздействия на экосистему (1). $\mathrm{BtH}_{14}$ рассматривается в качестве приоритетного биоагента в борьбе с кровососущими комарами - паразитами животных и человека и переносчиками трансмиссивных заболеваний, в том числе анаплазмоза крупного рогатого скота. Ущерб, причиняемый животноводству кровососущими двукрылыми, может выражаться в снижении удоев на 20-30 \%, прироста живой массы - на 20-40 \% (2).

В защите растений, в том числе сеяных кормовых культур, важной тенденцией также становится экологизация ассортимента средств борьбы с вредными организмами за счет применения биологических препаратов на основе бактерий (3-5), актиномицетов (6), энтомофторовых грибов и энтомопатогенных нематод $(7,8)$ как фактора оптимизации фитозащиты и питания сельскохозяйственных культур. Среди этих биоагентов также выделяются спорообразующие бактерии Bacillus thuringiensis (Bt) $(9,10)$, которые обладают комплексом полезных свойств: защищают сельскохозяйственные культуры от фитофагов $(11,12)$ и фитопатогенов $(13-15)$, могут стимулировать рост растений $(16,17)$, при этом безопасны для человека (18) и полезной энтомофауны $(19,20)$. Приоритетное место на рынке занимают биопрепараты на основе Bt как наиболее эффективные и безопасные для окружающей среды (21-23). В качестве действующего вещества они содержат спорокристаллический комплекс $(24,25)$, некоторые из них термостабильный экзотоксин $(26,27)$, а также ряд других менее изученных метаболитов и белковых факторов вирулентности (28-30).

Оптимально рентабельные препараты получают при использовании штамма-продуцента с высокой вирулентностью, технологичностью и безопасностью. Однако культура штаммов -продуцентов биопрепаратов подвержена популяционной изменчивости $(31,32)$. Длительное хранение, частые пересевы на плотные агаризованные среды приводят к образованию колоний различных морфотипов и ведут к некоторому снижению вирулентности (33). Так, штаммы Bt, которые хранили 28 лет в кристаллах хлорида натрия или в лиофилизированном виде, 10 лет (срок наблюдений) - в криоконсервированном состоянии, сохраняли $100 \%$ жизнеспособности, но проявляли ларвицидную активность на уровне 78-90\% в сравнении с исходными значениями.

В представленной работе мы впервые выполнили комплексный анализ выделенных кристаллогенных и акристаллогенных вариантов Bacillus thuringiensis var. israelensis $\left(\mathrm{BtH}_{14}\right)$ с использованием метода полимеразной цепной реакции (ПЦР) на ранней стадии развития культуры (18 ч). У изученных кристаллогенных вариантов выявлены гены, кодирующие целевые инсектицидные токсины Cry4 и Cry11, в то время как акристаллогенные этих генов лишены. При этом варианты не различались по основным биохимическим свойствам, морфологии вегетативной культуры и колоний на рыбном агаре (РА), а также по продуктивности. Установлено, что у кристаллогенных вариантов в отличие от акристаллогенных культуральная жидкость (КЖ) через 12 ч инкубации не образует осадка и приблизительно в 7000 раз активнее в отношении личинок Aedes aegypti.

Целью исследований было сравнение морфологические, биохими- 
ческие, технологические, ларвицидные свойства и наличия энтомоцидных токсинов Cry у вирулентных и авирулентных вариантов штаммов $\mathrm{BtH}_{14}$.

Методика. Штаммы $\mathrm{BtH}_{14}$ 404, 8728 лет хранили методом лиофилизации, затем 2 года в пробирках на скошенном рыбном агаре (PA) с пересевом каждые 6 мес; штамм 7-1/23 28 лет хранили в кристаллах $\mathrm{NaCl}$, затем 2 года в полученной КЖ при $3{ }^{\circ} \mathrm{C}$. Исходная продуктивность характеризовалась следующими значениями $\left(\times 10^{9}\right.$ КОЕ/мл): 3,96 $\pm 0,28 ; 4,4 \pm 0,22$;

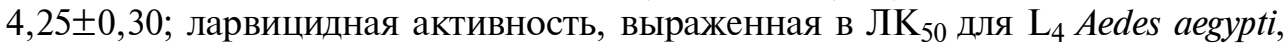
составляла соответственно $(0,135 \pm 0,01) \times 10^{-3} \%$; $(0,115 \pm 0,015)$ х $10^{-3} \%$; $(0,128 \pm 0,01) \times 10^{-3} \%$.

Штаммы $\mathrm{BtH}_{14}$ выращивали на скошенном РА при температуре $30{ }^{\circ} \mathrm{C}$ до полного образования спор и кристаллов.

Морфологию колоний изучали после рассева культуры $\mathrm{BtH}_{14}$ методом истощающегося мазка на рыбный агар (РА) стандартного состава в чашках Петри на 7-е сут роста при $30^{\circ} \mathrm{C}$. Использовали световую микроскопию (микроскоп Zeiss Axio Imager A2, «Carl Zeiss», Германия, иммерсионный объектив × 100) препаратов, окрашенных анилиновым черным («Lucar», Россия), отбирали кристаллогенные и акристаллогенные варианты (34) для анализа на наличие генов кристаллического токсина (35).

На дрожже-полисахаридной (регламентной) среде оценивали технологичность BtH14, выращивая культуру 68 ч глубинным способом при температуре $30{ }^{\circ} \mathrm{C}$ и аэрации 220 об/мин. Количество клеток, выросших на РА, определяли, используя стандартный способ серийных разведений. ЛК 50 (ларвицидную активность) для комаров Aedes aegypti учитывали согласно описанию (33).

Биохимические свойства (утилизация углеводов, образование ацетилметилкарбинола, индола и др.) изучали с использованием индикаторных дисков (СИБ, «Микроген», Россия) по прилагаемой инструкции. Культуру, выращенную на среде РА в течение 1 сут при $30{ }^{\circ} \mathrm{C}$, отбирали микробиологической петлей и помещали в стерильный раствор хлорида натрия $(0,85 \%)$. Через 5-18 ч проводили анализ биохимических свойств штаммов.

При выделении геномной ДНК для ПЦР-анализа бактерии выращивали на стандартной среде Лурия-Бертани (ЛБ) при $30{ }^{\circ} \mathrm{C}$ в течение 16-18 ч. Клетки суспендировали в буфере Tris-EDTA (1 M TrisHCl, pH 7,5 + 0,5 M EDTA, pH 8,0) и нагревали в течение 10 мин при $102{ }^{\circ} \mathrm{C}$. Остатки клеток удаляли осаждением при 15000 g в течение 3 мин. Надосадочную жидкость, содержащую геномную ДНК бактерий, переносили в эппендорфы и использовали для ПЦР-анализа (ДНК-амплификатор Т100, Bio-Rad, CША) (35, 36). Программу ПЦР-анализа подбирали, исходя из температуры отжига известных праймеров и величины амплифицируемого фрагмента ДНК. Реакционная смесь (20 мкл) содержала 1 мкл водной суспензии бактериальной ДНК (80 нг ДНК), 10 мкл смеси Fermentas DreamTaq green PCR master mix («Thermo Fisher Scientific», США), и 0,3 мкл каждого праймера (конечная концентрация 1 пмоль/мкл). Вирулентный штамм $\mathrm{BtH}_{10} 56$, относящийся к группе $B$. thuringiensis var. darmstadiensis, использовали в ПЦР в качестве негативного контроля. ПЦР-продукты анализировали с помощью электрофореза в $1 \%$ агарозном геле с окрашиванием 0,002 \% бромистым этидием.

Результаты обрабатывали методом дисперсионного анализа (37) с доверительным интервалом 95 \%. В таблицах представлены средние $(M)$ и стандартные ошибки средних ( \pm SEM).

Результаты. Штаммы $\mathrm{BtH}_{14}$ 404, 87, 7-1/23 после длительного хра- 
нения рассевали на РА в чашках Петри и провели целенаправленный отбор по двум критериям - образованию кристаллического эндотоксина и спор и по образованию только спор.

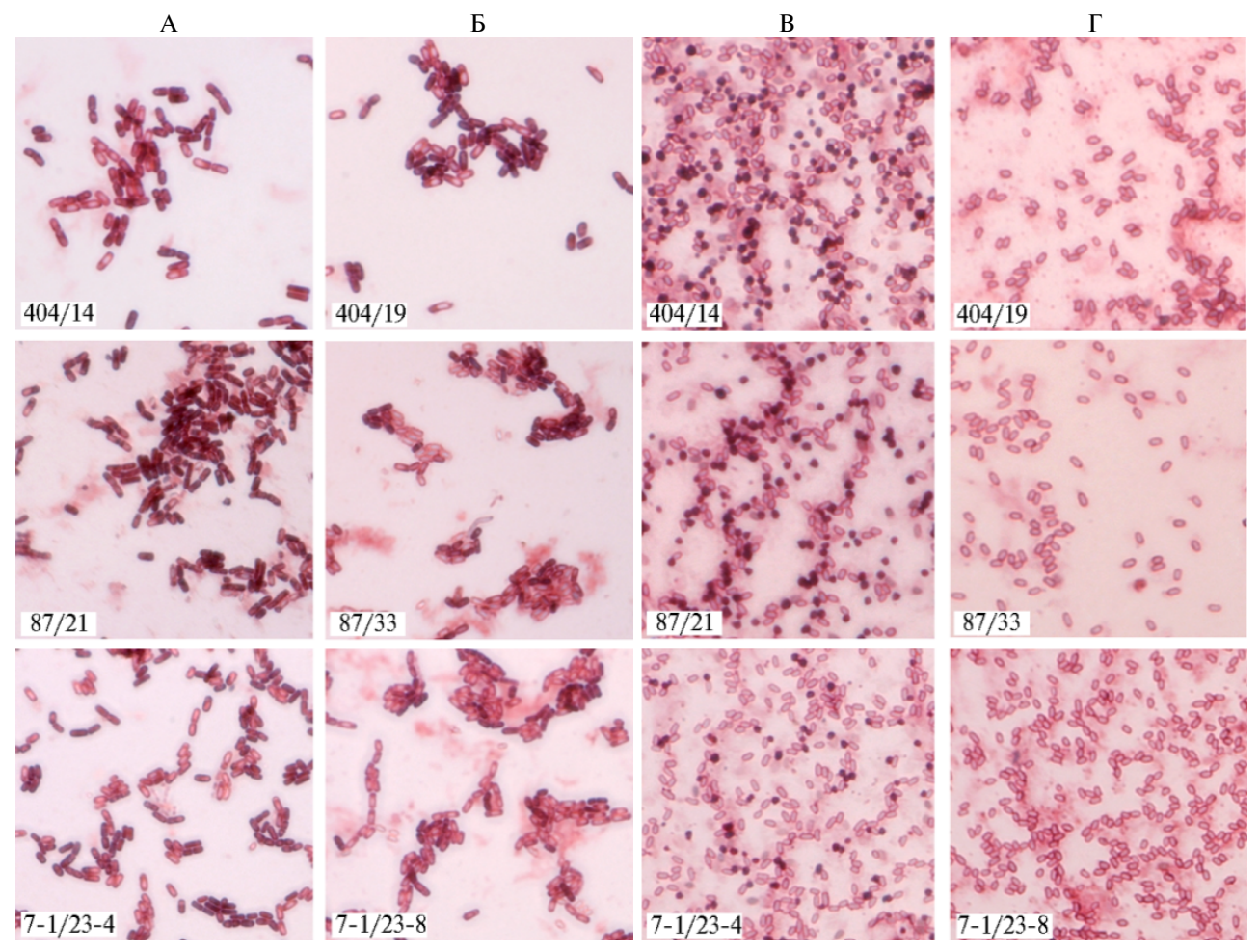

Рис. 1. Кристаллогенные (А, В) и акристаллогенные (Б, Г) варианты штаммов Bacillus thuringiensis var. israelensis $\left(\mathrm{BtH}_{14}\right)$ после 16 ч (А, Б) и 7 сут (В, Г) культивирования. Световая микроскопия (микроскоп Zeiss Axio Imager A2, «Carl Zeiss», Германия, иммерсионный объектив ×100) препаратов, окрашенных анилиновым черным («Lucar», Россия).

Для изучения отобрали варианты штаммов BtH $_{14}$ 404/14, 87/21, 71/23-4 (кристаллогенные) и 404/19, 87/33, 7-1/23-8 (акристаллогенные).

По морфологическим признакам культуры не различались: у всех вариантов колонии были шероховатые, плоские, матовые, серовато-белые, край волнистый, структура мелкозернистая, консистенция вязкая. Методом световой микроскопии 16-часовых культур мы также не выявили различий (рис. 1, А). Вместе с тем 7-суточные культуры исследуемых штаммов BtH14 морфологически существенно различались (см. рис. 1, Б).

Результаты изучения ларвицидных свойств у различных вариантов $\mathrm{BtH}_{14}$ приведены в таблице 1. Полученные данные показали, что технологичность кристаллогенных и акристаллогенных вариантов штаммов $\mathrm{BtH}_{14}$ была практически одинаковой - соответственно $(3,36 \pm 0,25-4,02 \pm 0,15) \times 10^{9}$ и $(3,74 \pm 0,19-4,13 \pm 0,15) \times 10^{9}$ КОЕ/мЛ.

Ларвицидная активность кристаллогенных вариантов $\mathrm{BtH}_{14}$, выраженная в $Л_{50}$ для $\mathrm{L}_{4} A$. aegypti, была практически одинаковой и находилась в пределах $(0,120 \pm 0,012-0,160 \pm 0,018) \times 10^{-3} \%$. Акристаллогенные варианты $\mathrm{BtH}_{14}$ были неактивными в отношении $\mathrm{L}_{4} A$. aegypti в общепринятых разведениях $(1,0 ; 0,5 ; 0,25 ; 0,125 ; 0,06) \times 10^{-3} \%$ КЖ, лишь $1 \%$ суспензия (концентрация в 7000 раз больше) вызывала гибель 22-39 \% личинок комаров через 24 ч, в то время как у активных вариантов та же концентрация приводила к $100 \%$ гибели уже через 15 мин.

Интересным был тот факт, что КЖ у неактивных вариантов через 
12 ч разделялась на осадок и надосадочный слой, а у активных - оставалась в состоянии взвеси (рис. 2). По нашим наблюдениям, КЖ вирулентного штамма $\mathrm{BtH}_{14}$ 7-1/23A во взвеси сохранялась до 3 лет.

1. Ларвицидные свойства изученных вариантов Bacillus thuringiensis var israelensis $\left(\mathrm{BtH}_{14}\right)(M \pm \mathrm{SEM}$, лабораторный опыт)

\begin{tabular}{l|l|c|c}
\hline \multicolumn{1}{c}{ Вариант } & $\begin{array}{l}\text { Результаты микроскопии } \\
\text { 7-суточной культуры }\end{array}$ & Титр спор, $\times 10^{9} /$ мл & ЛК $_{50}$ для $\mathrm{L}_{4}$ Aedes aegypti, $\times 10^{-3} \%$ \\
\hline $404 / 14$ & Споры, кристаллы & $3,36 \pm 0,25$ & $0,160 \pm 0,018$ \\
$404 / 19$ & Споры & $3,74 \pm 0,19$ & 0 \\
$87 / 21$ & Споры, кристаллы & $4,02 \pm 0,15$ & $0,120 \pm 0,012$ \\
$87 / 33$ & Споры & $4,13 \pm 0,15$ & 0 \\
$7-1 / 23-4$ & Споры, кристаллы & $3,95 \pm 0,10$ & $0,150 \pm 0,020$ \\
$7-1 / 23-8$ & Споры & $4,00 \pm 0,18$ & 0
\end{tabular}

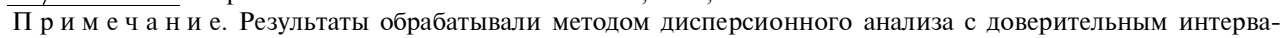
лом 95 \%. По продуктивности кристаллогенные штаммы (между собой) и в сравнении с акристаллогенными статистически достоверно не различались. По ларвицидной активности кристаллогенные штаммы достоверно отличались от акристаллогенных.

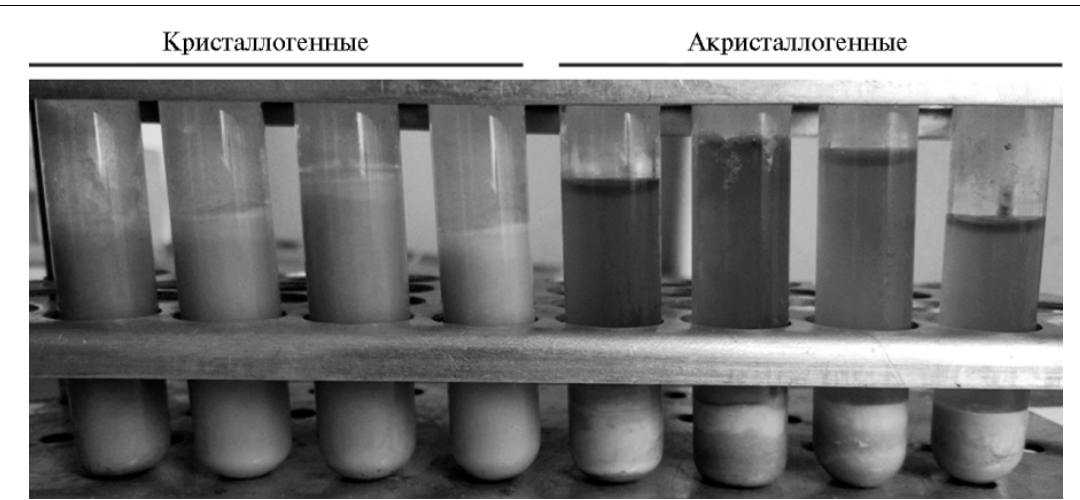

Рис. 2. Культуральная жидкость кристаллогенных вариантов Bacillus thuringiensis var. israelensis $\left(\mathrm{BtH}_{14}\right)$ через 12 ч инкубации при комнатной температуре образует взвесь, тогда как акристаллогенных - осадок.

Кристаллогенные (вирулентные) и акристаллогенные (авирулентные) вариантвы $\mathrm{BtH}_{14}$ не различались по проанализированному комплексу биохимических свойств. Так, они образовывали ацетилметилкарбинол и лецитиназу, гидролизовали крахмал, проявляли протеолитическую активность и не обладали уреазной. Штаммы метаболизировали глицерин, глюкозу, левулезу, мальтозу и маннозу, не усваивали арабинозу, галактозу, дульцит, ксилозу, лактозу, салицин, сахарозу, сорбит, целлобиозу и эскулин. Также они не образовывали пигмент, но формировали пленку на мясопептонном бульоне.

2. Праймеры, использованные для ПЦР-анализа кристаллогенных и акристаллических вариантов

\begin{tabular}{|c|c|c|c|c|}
\hline Праймер & Ген & $\begin{array}{l}\text { Олигонуклеотидная } \\
\text { последовательность }\left(5^{\prime} \rightarrow 3^{\prime}\right)\end{array}$ & Температура отжига, ${ }^{\circ} \mathrm{C}$ & Ссылка \\
\hline Cryl1 & cry 11 & $\begin{array}{l}\text { TTAGAAGATACGCCAGATCAAGC(f) } \\
\text { CATTTGTACTTGAAGTTGTAATCCC (r) }\end{array}$ & 45 & (38) \\
\hline Bti & & $\begin{array}{l}\text { CAAACATTTCATTCCAATAACA (f) } \\
\text { ATACTGTGTGGGATGCTTATTA (r) }\end{array}$ & 59 & (39) \\
\hline Cry4 & cry 4 & $\begin{array}{l}\text { GCATATGATGTAGCGAAACAAGCC(f) } \\
\text { ACCTGGAACATCTGACAACCAATC (r) }\end{array}$ & 62 & $\begin{array}{l}(40) \\
(35)\end{array}$ \\
\hline
\end{tabular}

Поскольку морфологически кристаллогенные (вирулентные) и акристаллогенные (авирулентные) варианты $\mathrm{BtH}_{14}$ не демонстрируют видимых различий, а формирование кристаллов происходит лишь через несколько суток инкубации, мы охарактеризовали кристаллогенные и акристаллогенные варианты штаммов $\mathrm{BtH}_{14}$ при помощи ПЦР, используя 18-часовые 
культуры. Использованные праймеры представлены в таблице 2.

C праймерами Bti амплифицируется последовательность нуклеотидов, которая специфична для $B$. thuringiensis var. israelensis и находится на хромосомной ДНК этих бактерий. Полученный положительный результат амплификации с праймерами Вti (табл. 3, рис. 3) подтвердил то, что изучаемые варианты относятся к $B$. thuringiensis var. israelensis. По результатам ПЦР-анализа, варианты 404/14, 87/21 и 7-1/23-4 несут гены cry4 и cry11. В случае вариантов 404/19, 87/33, 7-1/23-8 результаты амплификации с этими праймерами были отрицательными, что подтверждает отсутствие кристаллического эндотоксина и ларвицидной активности против $A$. aegypti.

3. Сравнительная характеристика кристаллогенных и акристаллогенных вариантов Bacillus thuringiensis var. israelensis с использованием ПЦР

\begin{tabular}{|c|c|c|c|c|}
\hline \multirow{2}{*}{ Вариант } & \multicolumn{3}{|c|}{ ПЦР с праймерами } & \multirow{2}{*}{ Кристаллогенность } \\
\hline & Bti & Cry 4 & Cry 11 & \\
\hline$\overline{404 / 14}$ & + & + & + & + \\
\hline $404 / 19$ & + & - & - & - \\
\hline $87 / 21$ & + & + & + & + \\
\hline $87 / 33$ & + & - & - & - \\
\hline $7-1 / 23-4$ & + & + & + & + \\
\hline $7-1 / 23-8$ & + & - & - & - \\
\hline
\end{tabular}

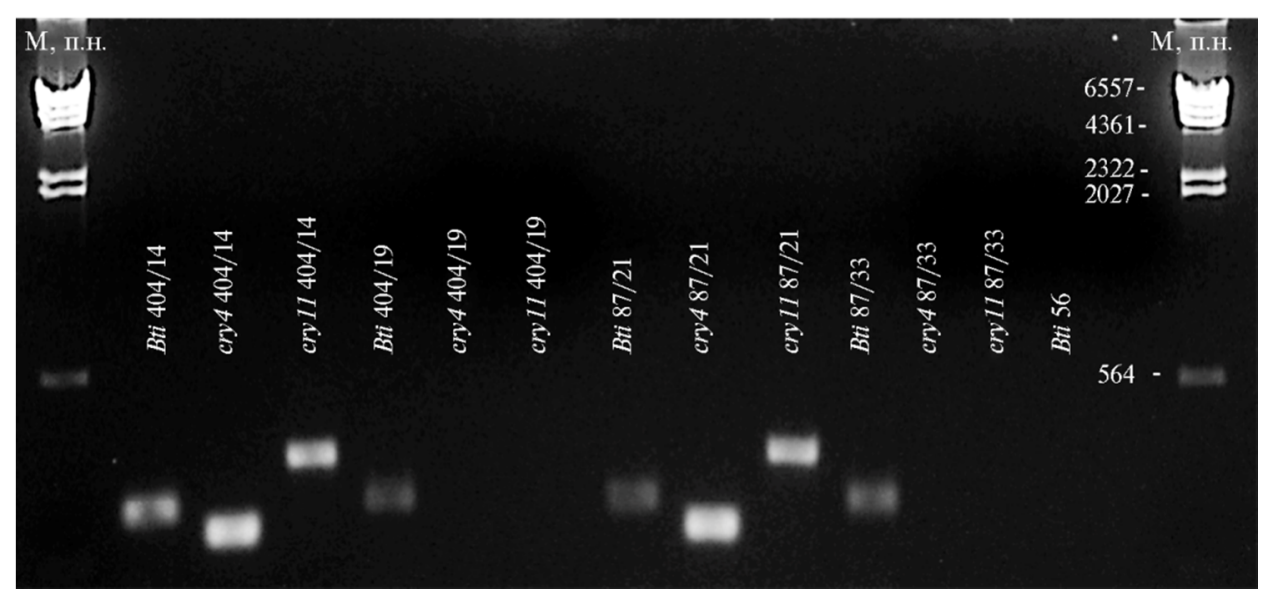

Рис. 3. Гель-электрофорез ПЦР-продуктов, полученных в результате амплификации ДНК вараинтов Bacillus thuringiensis var. israelensis с праймерами Bti, Cry4 и Сry11 для акристаллогенных и кристаллогенных штаммов. М - маркер молекулярных масс $\lambda$ ДНК/HindIII («Thermo Fisher Scientific», США). Указаны названия генов (в соответствии с использованными праймерами) и номера штаммов.

Таким образом, проведенные исследования позволили заключить, что вирулентные варианты Bacillus thuringiensis var. israelensis 404/14, 87/21, 7-1/23, в отличие от авирулентных 404/19,87/21, 7-1/23-8, несут гены, кодирующие инсектицидные токсины Cry4 и Cry11, образуют кристаллические эндотоксины, обладают высокой ларвицидной активностью (1 \% суспензия культуральной жидкости кристаллогенных вариантов вызывала $100 \%$ гибели личинок $A$. aegypti через 15 мин, акристаллогенных - лишь 22-39\% через 24 ч) и находятся в культуральной жидкости в виде взвеси, в отличие от авирулентных вариантов, которые образуют осадок уже через 12 ч. Для оценки производственных свойств штаммов B. thuringiensis var. israelensis быстрый скрининг можно выполнять методом полимеразной цепной реакции для определения наличия генов, кодирующих главные белковые токсины B. thuringiensis. Поскольку вирулентные и авирулентные варианты этих штаммов без длительного культивирования не демонстри- 
руют существенных морфологических и биохимических различий, наличие или отсутствие генов cry - наиболее удобный показатель для отбора перспективных штаммов. Применение молекулярно-генетических методов в работе со штаммами-продуцентами не исключает необходимости учитывать скорость споруляции и соотношение количества спор и белковых кристаллических включений методом световой микроскопии, а также контролировать титр штаммов как показатель их технологичности.

\title{
ФГБНУ Всероссийский НИИ сельскохозяйственной микробиологии, \\ 196608 Россия, г. Санкт-Петербург-Пушкин, ш. Подбельского, 3, \\ e-mail: ermolovavalya1940@mail.ru, svetagrishechkina@mail.ru, \\ m.belousova@arriam.ru, k.antonets@arriam.ru, a.nizhnikov@arriam.ru $\bowtie$; \\ Поступила в редакцию 19 июля 2019 года \\ Sel'skokhozyaistvennaya biologiya [Agricultural Biology], 2019, V. 54, № 6, pp. 1281-1289 \\ INSECTICIDAL PROPERTIES OF Bacillus thuringiensis var. israelensis. II. COMPARATIVE MORPHOLOGICAL AND MOLECULAR GENETIC ANALYSIS OF THE CRYSTALLOGENIC AND ACRYSTALLOGENIC STRAINS
}

\author{
V.P. Ermolova, S.D. Grishechkina, M.E. Belousova, K.S. Antonets, A.A. Nizhnikov
}

All-Russian Research Institute for Agricultural Microbiology, 3, sh. Podbel'skogo, St. Petersburg, 196608 Russia, e-mail ermolovavalya1940@mail.ru, svetagrishechkina@mail.ru, m.belousova@arriam.ru, k.antonets@arriam.ru, a.nizhnikov@arriam.ru ( $\square$ corresponding author) ORCID:

Ermolova V.P. orcid.org/0000-0002-9473-8334

Grishechkina S.D. orcid.org/0000-0002-4877-705X

Belousova M.V. orcid.org/0000-0002-2886-026X

Antonets K.S. orcid.org/0000-0002-8575-2601

Nizhnikov A.A. orcid.org/0000-0002-8338-3494

The authors declare no conflict of interests

Acknowledgements:

Supported financially by the project of applied research and experimental development (PNER) batch 2017-14579-0030 on the topic: «Creation of microbiological preparations for expanding the adaptive capacity of agricultural crops for nutrition, resistance to stress and pathogens» (code of the application 2017-14-579-0030-013), Agreement No. 14.607.21.0178, a unique identifier (project) RFMEFI60717X0178

Received July 19, 2019

doi: 10.15389/agrobiology.2019.6.1281eng

\section{Abstract}

Currently, the bacterium Bacillus thuringiensis var. israelensis represents a key agent for biological protection against dipteran species, which are harmful to livestock and crop production and transmit infectious diseases of economically important animals. The production strains can be obtained by isolation from natural resources, selection of previously used isolates, screening of genetic collections, and genetic or genomic engineering. The issue of preservation and control of practically valuable properties of strains is of high importance. Biologicals are of significant interest due to their substantial advantages over chemical pesticides and are considered in modern agricultural systems as environmentally and socially priority alternatives to agrochemicals. In the present work, we performed the first comprehensive comparative analysis of crystallogenic and acrystallogenic variants of Bacillus thuringiensis var. israelensis $\left(\mathrm{BtH}_{14}\right)$ isolated after storage of the strain in different modes. For crystallogenic variants, genes encoding the target insecticidal toxins, Cry4 and Cry11, were detected by the polymerase chain reaction (PCR), and it was shown that the acrystallogenic variants are devoid of these genes. It was found that the culture fluid of crystallogenic variants is approximately 7000 times more active against the Aedes aegypti larvae than the same of acrystallogenic. The aim of this work was to compare the morphological, biochemical, technological, larvicidal properties of the crystal-forming and acrystallogenic variants of the strains of Bacillus thuringiensis var. israelensis $\left(\mathrm{BtH}_{14}\right)$ and testing for the presence of genes encoding Cry insecticidal toxins, which are key determinants of virulence. We studied the strains 404 and 87 stored for 28 years by freeze-drying, then 2 years in test tubes on canted fish agar (FA) with replanting every 6 months; the 7-1/23 strain stored for 28 years in crystals of $\mathrm{NaCl}$, then 2 years in culture liquid $(\mathrm{CL})$ at $3{ }^{\circ} \mathrm{C}$. Bacterial strains were inoculated on Petri dishes to obtain separate colonies. On day 7 of growth, the 404/14, 87/21, 7 1/23-4 (crystal-forming) and 404/19, 87/33, 7-1/23-8 (acrystallogenic) variants were selected by microscopic analysis using aniline black dye. The differences in the colony morphology were not revealed: the colonies were flat, opaque, grayish-white, rough, rounded, the structure was finegrained, and the consistency was viscous. The differences either in the morphology of the vegetative cultures, or in the main biochemical properties (the formation of acetylmethyl carbinol, le- 
cithinase, the use of carbohydrates, the splitting of starch, etc.), or in the titer on the yeastpolysaccharide medium were not shown as well. The productivity of the $404 / 14,87 / 21,7-1 / 23-4$ and $404 / 19,87 / 33,7-1 / 23-8$ strains varied from $3.36 \times 10^{9} \mathrm{CFU} / \mathrm{ml}$ to $4.02 \times 10^{9} \mathrm{CFU} / \mathrm{ml}$ and from $3.74 \times 10^{9} \mathrm{CFU} / \mathrm{ml}$ to $4.13 \times 10^{9} \mathrm{CFU} / \mathrm{ml}$, respectively. The larvicidal activity of the crystalforming variants, expressed in $\mathrm{LC}_{50}$ for $\mathrm{L} 4$ Aedes aegypti, was $(0.12-0.16) \times 10^{-3} \%$, while acrystallogenic variants were inactive within the standard dilutions $\left(\times 10^{-3} \%\right) 1.0 ; 0.5 ; 0.25 ; 0.125 ; 0.06$. Only their $1 \%$ suspension (7000-fold higher concentration) caused 22-39\% death of the Aedes larvae after 24 hours; the same concentration of active variants resulted in $100 \%$ death in 15 minutes. It was established that cultural liquid of the acrystallogenic variants formed a precipitate and a supernatant layer after 12 hours, while the crystal-forming variants remained suspended. The investigated variants of $\mathrm{BtH}_{14}$ were analyzed for the presence of genes encoding insecticidal toxins. The results of the PCR analysis with the Bti-specific primers confirmed the belonging of the both crystal-forming and acrystallogenic variants to $\mathrm{BtH}_{14}$. It has been found that the 404/14, 87/21, 7-1/23-4 strains carry genes encoding the Cry4 and Cry11 insecticidal toxins, while 404/19, 87/33, 7-1/23-8 acrystallogenic variants are devoid of these genes agreeing with the absence of larvicidal activity against $A$. aegypti.

Cry11.

Keywords: Bacillus thuringiensis, culture liquid, larvicidal activity, insecticidal toxins, Cry4,

\section{REFERENCES}

1. Ben-Dov E. Bacillus thuringiensis subsp. israelensis and its dipteran-specific toxins. Toxins, 2014, 6(4): 1222-1243 (doi: 10.3390/toxins6041222).

2. Akbaev M.Sh., Vodyanov A.N., Kosminkov N.E., Yatusevich A.I., Pashkin P.I., Vasilevich F.I. Parazitologiya $i$ invazionnye bolezni zhivotnykh [Parasitology and invasive animal diseases]. Moscow, 2000 (in Russ.).

3. Polanczyk R.A., Pires da Silva R.F., Fiuza L.M. Effectiveness of Bacillus thuringiensis against Spodoptera frugipera (Lepidoptera: Noctuida). Brazilian Journal of Microbiology, 2000, 31(3) 165-167 (doi: 10.1590/S1517-83822000000300003).

4. Sessitsch A., Reiter B., Berg G. Endophytic bacterial communities of field grown potato plants and their plant growth promoting abilities. Canadian Journal of Microbiology, 2004, 50: 239-249 (doi: 10.1139/w03-118).

5. Kandybin N.V., Patyka T.I., Ermolova V.P., Patyka V.F. Mikrobiokontrol' chislennosti nasekomykh $i$ ego dominanta Bacillus thuringiensis [Insect microbiocontrol and its dominant Bacillus thuringiensis]. St. Petersburg-Pushkin, 2009 (in Russ.).

6. Scherwinski K., Wolf A., Berg G. Assessing the risk of biological control agents on the indigenous microbial communities: Serratia plyuthica HRO-C48 and Streptomyces sp. HRO-71 as model bacteria. Biocontrol, 2006, 52: 87-112 (doi: 10.1007/s10526-006-9006-8).

7. Lednev G.R., Novikova I.I. V sbornike: Biologicheskie sredstva zashchity rastenii, tekhnologii ikh izgotovleniya i primeneniya [In: Biological plant protection products, technologies for their manufacture and use]. St. Petersburg, 2005: 261-272 (in Russ.).

8. Danilov L.G. Vestnik zashchity rastenii, 2018, 3: 38-42 (in Russ.).

9. Lacey L.A., Grzywacz D., Shapiro-Ilan D.I., Frutos R., Brownbridge M., Goettel M.S. Insect pathogens as biological control agents: back to the future. Journal of Invertebrate Pathology, 2015, 132: 1-41 (doi: 10.1016/j.jip.2015.07.009).

10. Bravo A., Gill S.S., Soberon M. Mode of action of Bacillus thuringiensis Cry and Cyt toxins and their potential for insect control. Toxicon, 2007, 49: 423-435 (doi: 10.1016/j.toxicon.2006.11.022).

11. Arglo-Filho R.C., Loguercio L.L. Bacillus thuringiensis in an environmental pathogen and hostspecificity has developted as an adaptation to human-generated ecological nishes. Insects, 2014, 5(1): 62-91 (doi: 10.3390/insects5010062).

12. Mnif I., Ghribi D. Potential of bacterial derived biopesticides in pest management. Crop Protection, 2015, 77: 52-64 (doi: 10.1016/j.cropro.2015.07.017).

13. Naidar R., Deschamps A., Roudet J., Calvo-Garrido C., Bruez E., Rey P., Fermaud M. Multiorgan screening of efficient bacterial control agents against two major pathogens of grapevine. Biological Control, 2016, 92: 55-65 (doi: 10.1016/j.biocontrol.2015.09.003).

14. Heydari A., Pessaraki M. A review on biological control of fungal plant pathogens using microbial antagonists. Journal of Biological Sciences, 2010, 1(4): 273-290 (doi: 10.3923/jbs.2010.273.290).

15. Akram W., Mahboob A., Jave d A. Bacillus thuringiensis strain 199 can induce systemic resistance in tomato against Fusarium wilt. European Journal of Microbiology and Immunology, 2013, 3: 275-280 (doi: 10.1556/EuJMI.3.2013.4.7).

16. Choudhary D.K., Johri B.N. Interactions of Bacillus spp. and plants - with special reference to induced systemic resistance. Microbiological Research, 2009, 164(5): 493-513 (doi: 10.1016/j.micres.2008.08.007).

17. Kumar P., Dubey R.C., Mahshwari D.K. Bacillus strain isolated from rhizosphere showed plant growth promoting and antagonistic activity against phythopathogens. Microbiological Research, 
2012, 167(8): 493-499 (doi: 10.1016/j.micres.2012.05.002).

18. Raddadi N., Cherif A., Ouzari H., Marzorati M., Brusetti L., Boudabous A., Daffonchio D. Bacillus thuringiensis beyond insect biocontrol: plant growth promotion and biosafety of polyvalent strains. Annals of Microbiology, 2007, 57(4): 481-494 (doi: 10.1007/BF03175344).

19. Raymond B., Federici B.A. In defense of Bacillus thuringiensis, the safest and most successful microbial insecticide available to humanity - a response to EFSA. FEMS Microbiology Ecology, 2017, 93(7): fix084 (doi: 10.1093/femsec/fix084).

20. Al-Khamada A.D. Vestnik zashchity rastenii, 2009, 4: 54-62 (in Russ.).

21. Pane C., Villecco D., Campanile F., Zaccardelli M. Novel strains of Bacillus isolated from compost and compost-amended soils as biological control agents against soil-borne phytopathogenic fungi. Biocontrol Science and Technology, 2012, 22(12): 1373-1388 (doi: 10.1080/09583157.2012.729143).

22. Tao A., Pang F., Huang S., Yu G., Li B., Wang T. Characterization of endophytic Bacillus thuringiensis strains isolated from wheat plants as biocontrol agents against wheat flagsmut. Biocontrol Science and Technology, 2014, 24(8): 901-924 (doi: 10.1080/09583157.2014.904502).

23. The manual of biocontrol agents. British Protection Council Publication, Alton, V.K., 2014.

24. Al-Momani F., Obeidat M., Saasoun I., Mequam M. Serotyping of Bacillus thuringiensis isolates their distribution in different Jordanian habitats and pathogenecity in Drosophila melanogaster. World Journal of Microbiology and Biotechnology, 2004, 20: 749-753 (doi: 10.1007/s11274-0044517-X).

25. Choi Y.S., Cho E.S., Je Y.H., Roh J.Y., Chang J.H., Li M.S., Seo S.J., Sohn H.D., Jin B.R. Isolation and characterization of a strain of Bacillus thuringiensis subsp. morrisoni PG-14 encoding $\delta$-endotoxin Cry1Ac. Current Microbiology, 2004, 48: 47-50 (doi: 10.1007/s00284-003-4102-9).

26. Grishechkina S.D., Ermolova V.P., Kovalenko T.K., Antonets K.S., Belousova M.E., Yakhno V.V., Nizhnikov A.A. Polyfunctional properties of the Bacillus thuringiensis var. thuringiensis industrial strain 800/15. Agricultural Biology [Sel'skokhozyaistvennaya Biologiya], 2019, 54(3): 494-504 (doi: 10.15389/agrobiology.2019.3.494eng).

27. Grishechkina S.D., Ermolova V.P., Romanova T.A., Nizhnikov A.A. Search for natural isolates of Bacillus thuringiensis for development of ecologically friendly biologicals. Agricultural Biology [Sel'skokhozyaistvennaya Biologiya], 2018, 53(5): 1062-1069 (doi: 10.15389/agrobiology.2018.5.1062eng).

28. Shrestha A., Sultana R., Chae J.-C., Kim K., Lee K.-J. Bacillus thuringiensis C-25 which is rich in sell wall degrading enzymes efficiently control lettuce drop caused by Sclerotinia minor. Eur. J. Plant Pathol., 2015, 142(3): 577-589 (doi: 10.1007/s10658-015-0636-5).

29. Saber W.I.A. Ghoneem K.V., Al-Askar A.A., Rashad Y.M., Ali A.A., Rashad E.M. Chitinase production by Vacillus subtilis ATCC 11774 and its effect on biocontrol of Rhizoctonia disease of potato. Acta Biologica Hungarica, 2015, 66(4): 436-448 (doi: 10.1556/018.66.2015.4.8).

30. Malovichko Y.V., Nizhnikov A.A., Antonets K.S. Repertoire of the Bacillus thuringiensis virulence factors unrelated to major classes of protein toxins and its role in specificity of hostpathogen interactions. Toxins, 2019, 11: e11060347 (doi: 10.3390/toxins11060347).

31. Zhang M.-Y., Lovgren A., Low M.G., Landen R. Characterization of an avirulent pleiotropic of the insect pathogen Bacillus thuringiensis: reduced expression of flagellin and phosphlipases. Infection and Immunity, 1993, 61(12): 4947-4954.

32. Lebenko E.V., Sekerina O.A., Chemerilova V.I. Mikrobiologiya, 2005, 74(1): 87-91 (in Russ.).

33. Ermolova V.P., Grishechkina S.D., Nizhnikov A.A. Activity of insecticidal Bacillus thuringiensis var. israelensis strains stored by various methods. Sel'skokhozyaistvennaya Biologiya [Agricultural Biology], 2018, 53(1): 201-208 (doi: 10.15389/agrobiology.2018.1.201eng).

34. Smirnoff U.A. The formation of crystals in Bacillus thuringiensis var. thuringiensis Berliner before sporulation of temperature inculcation. J. Insect. Pathol., 1965, 2: 242-250.

35. Guidi V., Patocchi N., Lüthy, P., Tonolla M. Distribution of Bacillus thuringiensis subsp. israelensis in soil of a Swiss Wetland reserve after 22 years of mosquito control. Applied and Environmental Microbiology, 2011, 77(11): 3663-3668 (doi: 10.1128/AEM.00132-11).

36. Hansen B.M., Hendriksen N.B. Detection of enterotoxic Bacillus cereus and Bacillus thuringiensis strains by PCR analysis. Applied and Environmental Microbiology, 2001, 67(1): 185-189 (doi: 10.1128/AEM.67.1.185-189.2001).

37. Dospekhov B.A. Metodika polevogo opyta [Methods of field trials]. Moscow, 1973 (in Russ.).

38. Ben-Dov E., Zaritsky A., Dahan E., Barak Z., Sinai R., Manasherob R., Margalith Y. Extended screening by PCR for seven cry-group genes from field-collected strains of Bacillus thuringiensis. Applied and Environmental Microbiology, 1997, 63(12): 4883-4890.

39. Schneider S., Hendriksen N.B., Melin P., Lundstrцm J.O., Sundh I. Chromosome-directed PCR-based detection and quantification of Bacillus cereus group members with focus on $B$. thuringiensis serovar israelensis active against nematoceran larvae. Applied and Environmental Microbiology, 2015, 81(15), 4894-4903 (doi:10.1128/aem.00671-15).

40. Bravo A., Sarabia S., Lopez L., Ontiveros H., Abarca C., Ortiz A., Quintero R. Characterization of cry genes in a Mexican Bacillus thuringiensis strain collection. Applied and Environmental Microbiology, 1998, 64(12): 4965-4972. 